\title{
Dexamethasone-mediated regulation of death and differentiation of muscle cells. Is hydrogen peroxide involved in the process?
}

\author{
Arkadiusz ORZECHOWSKI ${ }^{\mathrm{a} *}$, Jean GRIZARD ${ }^{\mathrm{b}}$, Michał JANK ${ }^{\mathrm{a}}$, \\ Barbara GAJKOWSKA ${ }^{\mathrm{c}}$, Małgorzata ŁOKOCIEJEWSKA ${ }^{\mathrm{a}}$, \\ Magda ZARON-TEPEREK ${ }^{\mathrm{a}}$, Michał GODLEWSKI ${ }^{\mathrm{a}}$ \\ ${ }^{a}$ Department of Physiological Sciences, Faculty of Veterinary Medicine, \\ Warsaw Agricultural University, Warsaw, Poland \\ b Unité de Nutrition et Métabolisme Protéique, Centre de Clermont-Ferrand-Theix, \\ Institut National de la Recherche Agronomique, 63122 Saint-Genès-Champanelle, France \\ ${ }^{c}$ Laboratory of Cell Ultrastructure, M. R. C. Polish Academy of Sciences, Warsaw, Poland
}

(Received 23 November 2001; accepted 16 May 2002)

\begin{abstract}
The hypothetical involvement of $\mathrm{H}_{2} \mathrm{O}_{2}$ in dexamethasone-mediated regulation of muscle cell differentiation and elimination was studied. Rat L6 myoblasts and mouse C2C12 satellite cells were chosen for acute ( $24 \mathrm{~h}$ ) and chronic (5 or 10 day) experiments. Mitogenicity and anabolism were both affected by $\mathrm{H}_{2} \mathrm{O}_{2}$. Micromolar concentrations of $\mathrm{H}_{2} \mathrm{O}_{2}$ inhibited DNA while stimulating protein synthesis. At the millimolar level, $\mathrm{H}_{2} \mathrm{O}_{2}$ led to cell death by apoptosis. Synthetic glucocorticoid - dexamethasone (Dex) was shown to effect muscle cell fate similarly to $\mathrm{H}_{2} \mathrm{O}_{2}$. Chronic treatment with $\mathrm{H}_{2} \mathrm{O}_{2}$ or Dex dose-dependently accelerated either the formation of myotubes or cell elimination. Dexinduced cell death slightly differed from classical apoptosis and was featured by the symptoms of cell senescence such as extensive cytoplasm vacuolisation, accumulation of inclusion-bodies and lack of low molecular weight oligonucleosomal DNA fragmentation but chromatin condensation. Antioxidants (sodium ascorbate, $\mathrm{N}$-acetyl-L-cysteine, catalase) abrogated Dex-dependent cell death. We conclude that $\mathrm{H}_{2} \mathrm{O}_{2}$ directly influences myogenesis and muscle cell elimination. Moreover, $\mathrm{H}_{2} \mathrm{O}_{2}$ can be considered as the potent mediator of glucocorticoid-dependent effects on muscle cells.
\end{abstract}

muscle cell / hydrogen peroxide / differentiation / cell death

* Correspondence and reprints
E-mail: orzechowski@alpha.sggw.waw.pl 


\section{INTRODUCTION}

Over a century ago, the concept of hormesis postulated that biological systems are regulated by unknown molecules that at low doses stimulate but cause inhibition at higher levels or act in a reverse order [12]. Despite several attempts, neither an adequate explanation nor a mechanism of hormesis has been described. The most common dose-response curve showing hormesis is the $\beta$-curve with an upward-curving for elevated doses (at low range) followed by a downward-curving at a higher range of factor concentration. In this paper, we hypothesise that hydrogen peroxide is involved in the hormetic feature of curves illustrating cell responses to signals modulating cell growth, differentiation and death of muscle mononuclear cells.

Cellular signalling pathways could be considered as components of intracellular circuits that are generated by protein networks [41]. There are several examples cited in the literature that confirm the paradigm of rather different biological effects triggered by the stimuli of the same origin. For instance, insulin and IGF-1 are potent mitogens leading to the proliferation of myogenic cells, although the same cytokines enable muscle cell differentiation and myogenesis $[39,40]$. Thus qualitative differences in the final decision whether the cell would divide or differentiate might also be associated with the diversification of signalling pathways. These experiments showed that the biological outcome (proliferation vs. differentiation) is determined by the quantitative modulation of the signal threshold [29].

There are some indications that hydrogen peroxide $\left(\mathrm{H}_{2} \mathrm{O}_{2}\right)$ might be seriously predisposed to the role of the regulatory molecule, which enables protein modifications (directly by oxidation and indirectly by phosphorylation) and fluctuations of RTKs activity as well as downstream protein tyrosine kinases (PTKs) and other signalling molecules (docking or adaptor proteins, transcription factors). In response to certain stimuli, some cells can instantly form $\mathrm{H}_{2} \mathrm{O}_{2}$ intracellularly [4]. At the same time, $\mathrm{H}_{2} \mathrm{O}_{2}$ plays an active role in the control of multiple cellular processes. Even though the balance between the various stimulatory and inhibitory responses will ultimately determine the strength and duration of the signalling cascades following their initiation, $\mathrm{H}_{2} \mathrm{O}_{2}$ could be a moderator of such responses. The important issue, however, is the explanation of how molecules of $\mathrm{H}_{2} \mathrm{O}_{2}$ may either stimulate proliferation vs. differentiation or inhibit proliferation vs. differentiation. It is conceivable that the biological effects of $\mathrm{H}_{2} \mathrm{O}_{2}$ on cell growth might be influenced by the average abundance of this molecule. The oxidative property apparently determines the intracellular activity of $\mathrm{H}_{2} \mathrm{O}_{2}$ even though $\mathrm{H}_{2} \mathrm{O}_{2}$ is neither a free radical nor a strong oxidant. A growing body of evidence suggests that elevated levels of oxidation by $\mathrm{H}_{2} \mathrm{O}_{2}$ modulates growth performance by impact on cell proteins and gene expression [33]. It is thought, that cellular responses to higher concentrations of $\mathrm{H}_{2} \mathrm{O}_{2}$ (oxidative stress) includes desensitisation to insulin [16], growth retardation and finally cell death. Harmful effects of $\mathrm{H}_{2} \mathrm{O}_{2}$ and other ROS on the tissue level have been suggested to be the main causes of aging [17]. Free radicals of mitochondrial origin are especially important due to oxidative damage in mitochondrial DNA [7], although deleterious effects of $\mathrm{H}_{2} \mathrm{O}_{2}$ to the cell seem to be dependent on concentration rather than the "place of birth" [14]. The action of $\mathrm{H}_{2} \mathrm{O}_{2}$ might be a causal factor where a similar input can therefore generate a different output in a different cellular context. In order to conceive the existence of such a feedback mechanism related to the regulation of muscle cell development at the molecular level, one should admit the generation of hydrogen peroxide at substantially different amounts. In recent years, it has become apparent that $\mathrm{H}_{2} \mathrm{O}_{2}$ can be formed directly or indirectly at different 
cellular localisations (plasma membrane, cytosol, mitochondria, peroxisomes, nucleus) by several enzymes and enzyme complexes. Superoxide dismutases $(\mathrm{Cu}-\mathrm{Zn}$ SOD; MnSOD; EC SOD) are specifically involved in the synthesis of $\mathrm{H}_{2} \mathrm{O}_{2}$, whereas several other enzymes that generate the superoxide anion radical i.e. NAD(P)H oxidases (low and high output synthases), xanthine oxidase (XO), cyclooxygenase or lipooxygenase indirectly provide the main substrate to SODs for $\mathrm{H}_{2} \mathrm{O}_{2}$ synthesis [11]. Additionally, hydrogen peroxide is the intermediate of the respiratory chain reaction where oxygen is gradually reduced to water $\left(\mathrm{H}_{2} \mathrm{O}\right)$. $\mathrm{H}_{2} \mathrm{O}_{2}$ is also the product of other oxidoreductases (cytochrome p450). Certain amounts of $\mathrm{H}_{2} \mathrm{O}_{2}$ formed in the mitochondria, microsomes and peroxisomes leak to the cytosol and are immediately subjected to reduction by antioxidant systems. Thus, as it has been shown, the abundance of $\mathrm{H}_{2} \mathrm{O}_{2}$ does not ultimately result from its de novo synthesis but it could also be the outcome of the impaired antioxidant status of the cell. There is good evidence that the catalytic efficacy of antioxidant enzymes e.g. glutathione peroxidase (GPx) and/or catalase is critical to limit intracellular $\mathrm{H}_{2} \mathrm{O}_{2}$ level within certain limits that back up the vital processes within the cell. According to this view, Briehl et al. [10] demonstrated that cell lines of lymphoid origin are susceptible to dexamethasone-induced disturbances in redox homeostasis. In a series of in vitro experiments these authors have shown that dexamethasone represses the activity of genes encoding antioxidant enzymes leading to impaired viability and apoptotic cell death $[5,9]$. Our own in vivo study performed on rats corroborates the working hypothesis that high doses of glucocorticoids are involved in the suppression of antioxidant defense systems and lead to growth retardation and muscle cachexia [34]. Muscle cells proliferate in growth-promoting conditions while becoming post-mitotic and fusing into multinucleated myotubes when deprived of serum mitogens. On the contrary, degenerative changes caused by ROS are best manifested in post-mitotic cells [31]. In this paper we addressed the question of how $\mathrm{H}_{2} \mathrm{O}_{2}$ influences growth, differentiation and death of muscle cells and whether $\mathrm{H}_{2} \mathrm{O}_{2}$ contributes to the glucocorticoid-dependent regulation of myogenesis. A clonal line of L6 muscle cells or $\mathrm{C} 2 \mathrm{C} 12$ mouse satellite cells were subjected to this study because these cells are ideally suited to the examination of dose-response effects of $\mathrm{H}_{2} \mathrm{O}_{2}$.

\section{MATERIALS AND METHODS}

\subsection{Media and reagents}

All reagents such as trichloroacetic acid (TCA), bovine serum albumin (BSA), dexamethasone, 7'-amino-actinomycin D (7'-AAD), sodium ascorbate (ASC), $\mathrm{N}$-acetyl-L-cysteine (NAC), hydrogen peroxide $\left(\mathrm{H}_{2} \mathrm{O}_{2}\right)$, catalase typical bovine (CAT), dimethylsulphoxide (DMSO), proteinase K, RNase A from the bovine pancreas and Lambda DNA EcoRI HindIII Digest were cell culture tested, of high purity, and unless otherwise stated they were purchased from the Sigma-Aldrich Chemical Co. (St. Louis MO, USA). The reagents were dissolved according to the producer's recommendations and stored as stock solutions (1000-fold the highest working concentration). Serum, media and antibiotics were from Gibco Life Technologies (Paisley, United Kingdom). Phosphate buffered saline (PBS) and ultra pure agarose were also obtained from Gibco BRL (USA). Reagents were prepared freshly prior to the experiments and added as $0.1 \%(\mathrm{v} / \mathrm{v})$ of the final volume.

\subsection{Cell culture}

Rat L6 muscle cells and the murine C2C12 myoblastic cell line (satellite cells) purchased from the European Collection of 
Animal Cell Cultures (ECACC) were maintained in the exponential phase of growth (20\% (v/v) FBS/DMEM with Glutamax) designed as GM (growth medium) supplied with an antibiotic-antimycotic mixture (Penicillin $\mathrm{G}$ sodium salt $50 \mathrm{IU} \cdot \mathrm{mL}^{-1}$, Streptomycin sulphate $50 \mu \mathrm{g} \cdot \mathrm{mL}^{-1}$ Gentamycin sulphate $20 \mu \mathrm{g} \cdot \mathrm{mL}^{-1}$ Anti PPLO agent Tylocine base $6 \mu \mathrm{g} \cdot \mathrm{mL}^{-1}$ Fungizone Amphotericin B $1 \mu \mathrm{g} \cdot \mathrm{mL}^{-1}$ ), in a controlled humidified air atmosphere supplied with $5 \% \mathrm{CO}_{2}$, at $37^{\circ} \mathrm{C}$.

\subsection{Experimental procedure}

Prior to each medium replacement, the cells were washed twice with phosphate buffered saline with $\mathrm{Ca}^{2+}$ and $\mathrm{Mg}^{2+}(\mathrm{PBS}+)$. During propagation, the medium was changed every other day. Confluent cells (fully covering surface dish) were then guided to a post mitotic status, and differentiation and fusion were initiated by replacing GM with $2 \%$ (v/v) horse serum HS/DMEM designed as DM (differentiating medium). In the above mentioned conditions L6 myoblasts (12 days) and $\mathrm{C} 2 \mathrm{C} 12$ satellite cells (5 days) can easily and fully differentiate into myotubes, therefore we could follow up on modifications of the differentiation process during subsequent days. Freshly prepared media without or with the experimental factors were changed every $24 \mathrm{~h}$ during acute or chronic studies performed on $\mathrm{C} 2 \mathrm{C} 12$ muscle cells or every other day during a chronic study on L6 myoblasts. Cells were propagated in a multiwell (24 or 96) or in multiwell (8) LabTek Chamber Slide w/Cover (Permanox Slide Sterile, Nalge Nunc International, Naperville, IL, USA). During the acute study the cells were initially grown until they reached $60 \%$ confluence while $100 \%$ confluence had to be achieved for chronic treatments. Subsequently, the cultures were treated for $24 \mathrm{~h}$ (acute treatment of L6 myoblasts) or 10 days (chronic treatment of L6 myoblasts) or 5 days (chronic treatment of $\mathrm{C} 2 \mathrm{C} 12$ satellite cells) with increasing doses of experimental factors (control cultures received 2\% HS/DMEM).

\subsection{Mitochondrial respiration (viability)}

Based on the mitochondrial function, the assessment of cell viability was evaluated on the basis of the ability of cells to convert soluble MTT (3-[4,5-dimethylthiazol-2yl]-2-5-diphenyltetrazolium bromide) into an insoluble purple formazan reaction product. This was done with minor modifications to the protocol described by Jacobson et al. [22]. For this assay, the cells were plated into 96 -well plates at $5 \times 10^{3}$ cells per well in $100 \mu \mathrm{L}$ complete medium $(2 \%$ HS/DMEM) with or without the experimental agents, and for the last $4 \mathrm{~h}$ of incubation these media were supplied with $100 \mu \mathrm{L}$ of an MTT working solution (0.5 mg. $\mathrm{L}^{-1}$ DMEM without phenol red, sterilised by filtration). The medium was aspirated and formazan was dissolved by addition of $100 \mu \mathrm{L}$ dimethylsulfoxide (DMSO, Merck). The absorbance (570-630 nm) was measured with an ELISA Reader type ELx808, BIO-TEK Instruments (USA). Percent viability (MTT conversion into purple formazan against a control value of $2 \%$ FBS/DMEM) indicates the rate of cell viability (mitochondrial respiration).

\subsection{Cytochemistry}

Cytotoxicity of $\mathrm{H}_{2} \mathrm{O}_{2}$ was strictly associated with cell death, which was confirmed by microscopic observations using a phasecontrast microscope (Olympus BX-20), or a BX-60 Olympus fluorescence microscope equipped with a PM20 automatic photomicrographic system after serial staining of living and dead cells. Morphological evaluation of the treated myoblasts was performed with labelling of DNA by both propidium iodide with $\mathrm{RNase}$ followed by Hoechst 33342 staining to distinguish live, 
necrotic, early- and late-apoptotic cells based on the method described by Abu-Shakra et al. [1]. In ultraviolet light, one thousand nuclei in total were counted in ten (or more if necessary) randomly chosen visual fields per slide (if possible, since some treatments were accompanied by extensive cell detachment) and cells were qualified as follows: regular oval shaped blue nuclei (live cells); partially shrunk blue nuclei (early apoptotic) or condensed white-blue nuclei (late apoptotic); regular oval shaped or condensed pink nuclei (dead cells regardless of origin - apoptotic or necrotic).

\subsection{Mitogenicity and anabolism}

Simultaneous pulsatile labelling with $\left[{ }^{3} \mathrm{H}\right]$-methyl-thymidine and $\left[{ }^{14} \mathrm{C}\right]$-leucine (Amersham PLC, $1 \mu \mathrm{Ci} \cdot \mathrm{mL}^{-1}$ ) was used for $6 \mathrm{~h}$ prior to the end of the experiment (18-24th h of treatment) to determine both the proliferation assay (mitogenicity) and protein synthesis (anabolism). The TCA $(5 \% \mathrm{w} / \mathrm{v})$ precipitable fraction of cells was dissolved in $0.5 \mathrm{M} \mathrm{NaOH} / 0.2 \%$ v/v Triton X-100 (24 h, $37^{\circ} \mathrm{C}, 95 \%$ humidity), the solutions obtained were neutralised with equivalent concentrated formic acid ( $5 \mathrm{~N}$ $\mathrm{HCOOH})$, mixed with a scintillation cocktail (Ultima Gold, Packard, USA) and counted in a Packard TRI-CARB 1600 CA $\beta$-counter. The results obtained in c.p.m. were expressed as \% values (control = $100 \%)$.

\subsection{Oligonucleosomal fragmentation of DNA}

DNA fragmentation was detected on the basis of oligonucleosomes localised in the DNA, isolated from the cells representing treatments, which was further evidenced by microscopic observation of apoptosis. The cells cultured in Petri dishes $(60 \mathrm{~mm}$ diameter) and treated with cytotoxic factors were removed with a cell scraper and mixed with medium. Briefly, approximately $1 \times 10^{6}$ the cells were centrifuged $(10000 \mathrm{~g}, 10 \mathrm{~min}$, $4{ }^{\circ} \mathrm{C}$ ) the supernatant was aspirated, the whole cell lysates were prepared by triturating in $15 \mu \mathrm{L}$ of sterile de-ionised water and were vortexed for $1 \mathrm{~s}$. Six microliters of an RNase A solution $\left(10 \mathrm{mg} \cdot \mathrm{mL}^{-1}\right.$ in $10 \mathrm{mM}$ Tris, $15 \mathrm{mM}$ sodium acetate, $\mathrm{pH} 7.5$, previously heated at $95^{\circ} \mathrm{C}$ for $15 \mathrm{~min}$ ) were added to each tube. The samples were mixed and incubated in a water bath at $56{ }^{\circ} \mathrm{C}$ for $1 \mathrm{~h}$. Proteinase $\mathrm{K}\left(20 \mathrm{mg} \cdot \mathrm{mL}^{-1}\right)$ was added to the gel cooled to $55^{\circ} \mathrm{C}$. Running and digestion gels were prepared by dissolving $1.8 \mathrm{~g}$ or $0.6 \mathrm{~g}$ agarose in TAE buffer $1.8 \%$ (w/v) (10 mM Tris, $10 \mathrm{mM}$ sodium acetate, $1 \mathrm{mM}$ EDTA), respectively. Ten microliters of loading buffer $(40 \%$ sucrose in water, $0.25 \%$ bromophenol blue $(\mathrm{w} / \mathrm{v}))$ were added to the cell lysates and vortexed. When the gel became solid, $15 \mu \mathrm{L}$ of each sample were transferred into each well. One microliter of $\lambda$ DNA EcoRI HindIII Digest (125-21 226 bp; Sigma Chemical Co., St. Louis, MO, USA) mixed with $10 \mu \mathrm{L}$ TAE and $5 \mu \mathrm{L}$ of the loading buffer was applied to each gel to provide a size marker. Electrophoresis of DNA was initially performed with $2 \mathrm{~V} \cdot \mathrm{cm}^{-1}$ ( 20 Volts) for $1 \mathrm{~h}$, followed by $3 \mathrm{~h}$ with $8 \mathrm{~V} \cdot \mathrm{cm}^{-1}$ ( $\left.80 \mathrm{Volts}\right)$ with TAE as a running buffer. After completion of electrophoresis, the gels were stained for 20 min with ethidium bromide $\left(1 \mu \mathrm{g} \cdot \mathrm{mL}^{-1}\right)$ followed by $5 \mathrm{~min}$ washing with de-ionised water. The gels were then UV illuminated and photographed with the Biometra BioDoc II video imaging system (USA). Analysis was repeated with the use of the remaining sample material.

\subsection{Determination of intracellular $\mathrm{H}_{2} \mathrm{O}_{2}$}

Reactive oxygen species were detected in situ with the use of 2',7'-dichlorofluorescein-diacetate (DCFH-DA) (Molecular Probes Inc.). DCFH-DA was dissolved in absolute ethanol at a concentration of $10 \mathrm{mmol} \cdot \mathrm{L}^{-1}$ and kept frozen under gaseous $\mathrm{N}_{2}$. 
L6 muscle cells were propagated in a multiwell (8) Lab-Tek Chamber Slide w/Cover (Permanox Slide Sterile, Nalge Nunc International, Naperville, IL, USA) and treated (or untreated) with experimental factors present in the differentiation medium $(2 \%$ HS/DMEM). On culture day 3, the cells were washed twice with PBS+ (including $\mathrm{Ca}^{2+}$ and $\left.\mathrm{Mg}^{2+}\right)$ and the wells were filled with $200 \mu \mathrm{L}$ PBS containing $0.1 \%$ BSA $(w / v)$. A volume of stock solution of DCFHDA was added to a final concentration of $10 \mu \mathrm{M}$ and the cells were incubated at $37^{\circ} \mathrm{C}$ for $1 \mathrm{~h}$. In order to select the death cells, the cells were stained with $7^{\prime}$-AAD $\left(5 \mu \mathrm{g} \cdot \mathrm{mL}^{-1}\right)$ for the last $45 \mathrm{~min}$ (alive cells resist staining of nuclear DNA). The cells were removed from the incubator, washed with PBS and mounting medium was used to avoid quenching and the cells were covered with cover slips. The cells were visualised using a FV-500 Confocal system (Olympus Optical Co., Hamburg, Germany). A 488 nm and $543 \mathrm{~nm}$ He-Ne laser beam provided the fluorescence excitation. The fluorescence was measured using dichroic mirrors and filters for $505,525 \mathrm{~nm}, 560$ and $610 \mathrm{~nm}$ wavelengths. Acquired data were stored in a series of 12 bit grey images, separately for each channel and were coloured artificially by software. The images were gathered as single slides. The data gathered were then stored in 24 bit TIFF format and transferred to Microimage software (Olympus Optical Co. Hamburg, Germany) for colour analysis. The fluorescence intensity for treated cells was determined and compared with control cells $(0.1 \%$ BSA/PBS $)$. Additionally, a positive control was ascertained with $1 \mathrm{~h} \mathrm{H}_{2} \mathrm{O}_{2}(100 \mu \mathrm{M})$ pre-treatment so as to prove the specificity of DCFH-DA to detect $\mathrm{H}_{2} \mathrm{O}_{2}$.

\subsection{Ultrastructural studies}

The cells were fixed in $2 \%$ para-formaldehyde and $2.5 \%$ glutaraldehyde in $0.1 \mathrm{M}$ sodium cacodylate buffer ( $\mathrm{pH}$ 7.4) for $2 \mathrm{~h}$ at
$4{ }^{\circ} \mathrm{C}$. After fixation they were washed in the same buffer and post-fixed with $1 \%$ $\mathrm{OsO}_{4}$ in $0.1 \mathrm{M}$ sodium cacodylate buffer for $1 \mathrm{~h}$. The cells were dehydrated in a graded ethanol alcohol series, and embedded in Epon 812. Ultrathin sections were stained with uranyl acetate and lead citrate and examined and photographed with a JEOL 1200XE electron microscope.

\subsection{Statistical analysis}

The results were statistically evaluated with one-way ANOVA and the Tukey multiple range test if compared to the control treatment, or by two-way ANOVA with the Benferroni post-test to compare replicate means between the treatments. These analyses were done using the GraphPad Prism ${ }^{\mathrm{TM}}$ version 2.00 software (GraphPad Software Inc., San Diego, CA, USA). In order to show the quantitative differences, arbitrary units: $\%$ of control values [experimental value/control value $\times 100$ ] were used. The means within the reference treatment that differ at least significantly $(P<0.05)$ are marked by different lowercase letters. The means that differ statistically between the treatment means and the reference treatment are marked with asterisks $(* P<0.05$; $* * P<0.01$; $* * * P<0.001)$. Each experiment was carried out in triplicate and was repeated at least twice.

\section{RESULTS}

Hydrogen peroxide $\left(\mathrm{H}_{2} \mathrm{O}_{2}\right)$ at the concentrations of 1,10 and $100 \mu \mathrm{M}$ significantly stimulated protein synthesis in L6 muscle cells by $52 \%, 90 \%$ and $54 \%$, respectively (Fig. 1). Simultaneously, mitogenic response to $\mathrm{H}_{2} \mathrm{O}_{2}$ was unaltered but at the higher concentration $(100 \mu \mathrm{M}), \mathrm{H}_{2} \mathrm{O}_{2}$ significantly reduced DNA synthesis (mitogenicity) by $22 \%$ (Fig. 1). We postulated that at micromolar concentrations $\mathrm{H}_{2} \mathrm{O}_{2}$ exerts an anabolic effect, although above $100 \mu \mathrm{M} \mathrm{H}_{2} \mathrm{O}_{2}$ is apparently antimitogenic. 
Substantial inhibition of the mitogenicity and protein synthesis were noticed at $\mathrm{H}_{2} \mathrm{O}_{2}$ concentrations higher than $100 \mu \mathrm{M}$ (Fig. 1). These results indicate the possible suppression of muscle regeneration, hyperplasticity and hypertrophy in conditions favouring excessive hydrogen peroxide formation. Thus, the biological effects exerted by $\mathrm{H}_{2} \mathrm{O}_{2}$ on rat L6 muscle cells seem to be dose-dependent. After $1 \mathrm{mM} \mathrm{H}_{2} \mathrm{O}_{2}$, the symptoms of apoptosis were evident when

\section{Mitogenicity in L6 muscle cells}

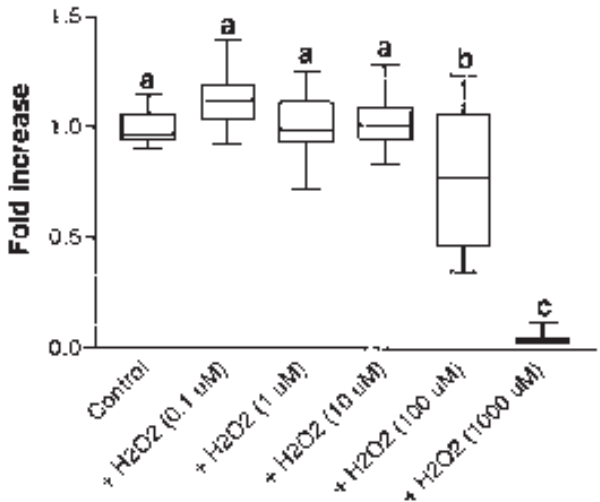

Protein syrithesis in L6 muscle cells

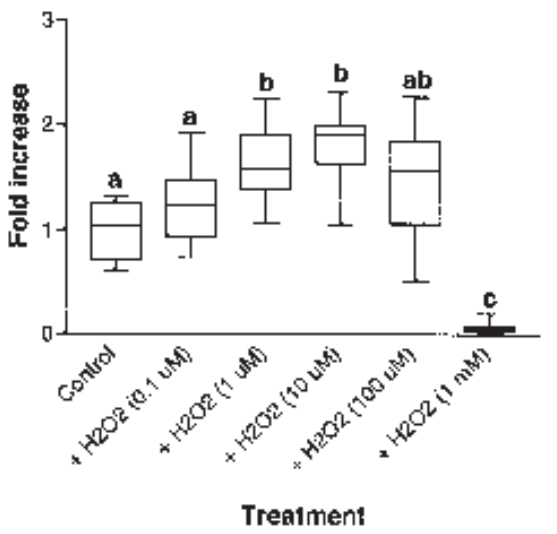

Figure 1. Mitogenicity (up) and anabolism (bottom) affected by $\mathrm{H}_{2} \mathrm{O}_{2}$. Rat $\mathrm{L} 6$ muscle cells were incubated for $24 \mathrm{~h}$ with $\mathrm{H}_{2} \mathrm{O}_{2}(0.1,1,10,100$, $1000 \mu \mathrm{M})$. Typical results from three experiments are shown as the means \pm SD/SEM of triplicate assays. cytochemical analyses were based on serial staining of nuclear DNA with fluorochromes (data not shown). The apoptotic index was calculated for control and experimental treatments by scoring the number of apoptotic nuclei vs. all nuclei. Necrotic cells were found as reddish nuclei. In general, the cells which were detached and collected in suspension, were necrotic (anoikis), whereas those remaining on the Lab-Tek slides were alive or apoptotic. Almost $92 \%$ of the cells died by apoptosis after 1-day of treatment with $1 \mathrm{mM} \mathrm{H}_{2} \mathrm{O}_{2}$ (data not shown). This result suggests that after reaching a certain level, $\mathrm{H}_{2} \mathrm{O}_{2}$ induces massive apoptosis in rat mononuclear L6 myoblasts. Morphological criteria of apoptosis were corroborated by the presence of oligonucleosomal DNA in the electrophoregrams from wholecell lysates after addition of $\mathrm{H}_{2} \mathrm{O}_{2}(1 \mathrm{mM})$ (Fig. 2).

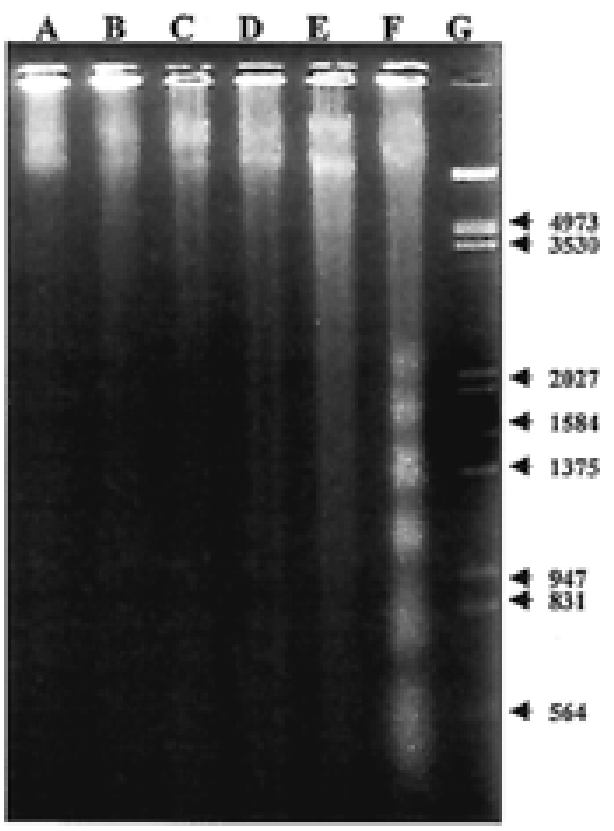

Figure 2. Agarose gel electrophoresis of DNA from whole-cell lysates obtained after 4 days of treatment with increased doses of $\mathrm{H}_{2} \mathrm{O}_{2}(0.1,1$, 10, 100, $1000 \mu \mathrm{M})$. A: control, B: $0.1 \mu \mathrm{M}$, C: $1 \mu \mathrm{M}, \mathrm{D}: 10 \mu \mathrm{M}, \mathrm{E}: 100 \mu \mathrm{M}, \mathrm{F}: 1000 \mu \mathrm{M}$, G: DNA molecular weight marker. 
$\mathrm{Zn}$-Cu-superoxide dismutase (SOD-1) is a very potent enzyme that causes dismutation of the superoxide anion radical $\left(\mathrm{O}_{2}{ }^{-}\right)$ into $\mathrm{H}_{2} \mathrm{O}_{2}$ and $\mathrm{O}_{2}$. On the contrary, catalase is an enzyme that dismutates $\mathrm{H}_{2} \mathrm{O}_{2}$ into $\mathrm{H}_{2} \mathrm{O}$ and $\mathrm{O}_{2}$. It means, that if they "stay in line", both enzymes efficiently scavenge ROS. In non-stimulated L6 muscle cells, increased doses of SOD-1 led to the simultaneous elevation of mitogenicity and protein synthesis, while catalase was apparently antimitogenic and anabolic. Both enzymes when added simultaneously, ameliorated mitogenicity and protein synthesis, although without a dose-response appearance (Fig. 3).
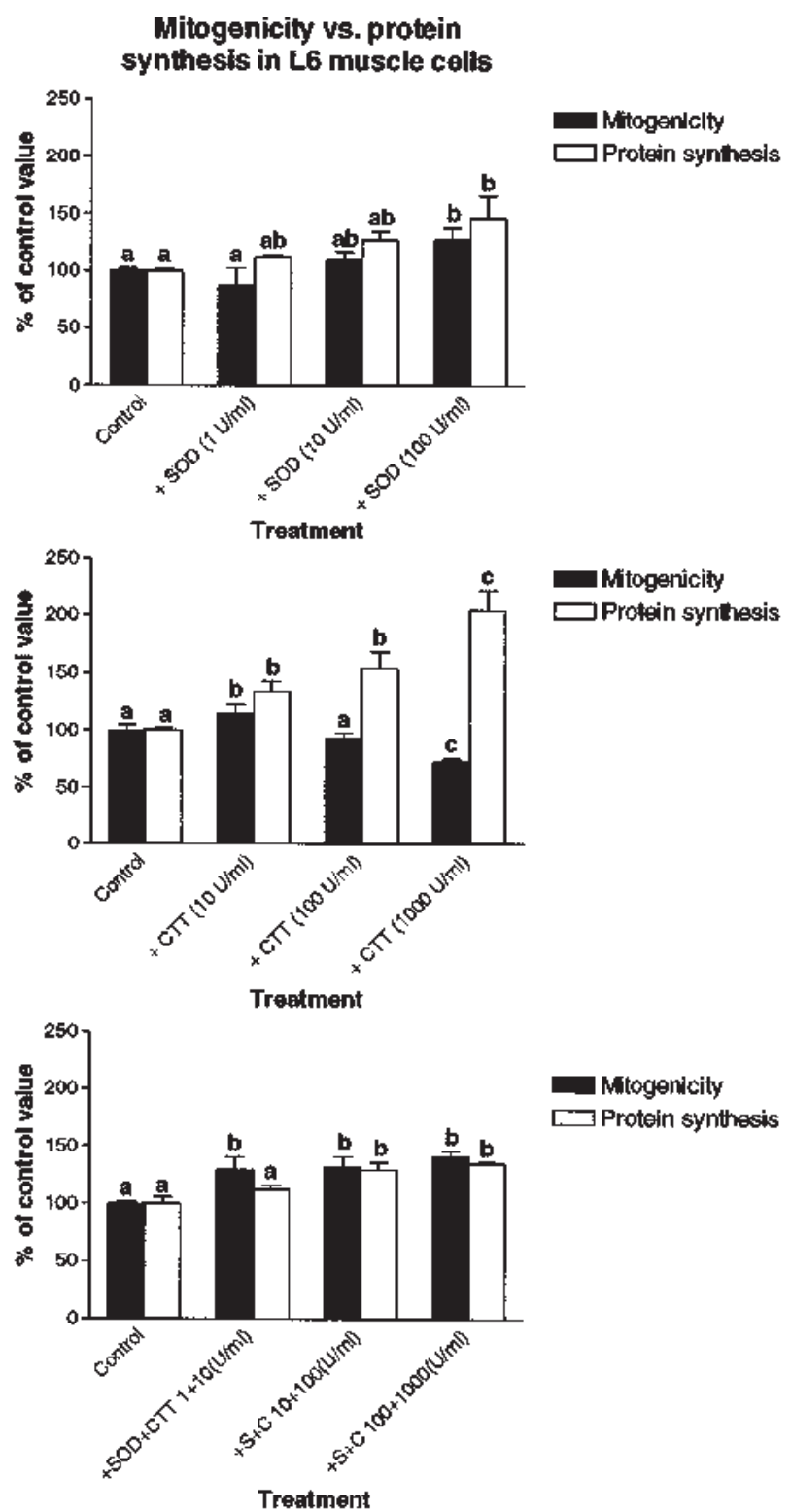

Mitogenicity Protein synthesis

Figure 3. The effect of $24 \mathrm{~h}$ of treatment with either SOD-1 (SOD) $\left(1,10,100 \mathrm{U} \cdot \mathrm{mL}^{-1}\right)$ or catalase (CTT) $\left(10,100,1000 \mathrm{U} \cdot \mathrm{mL}^{-1}\right)$ or both on mitogenicity and protein synthesis in L6 muscle cells. Typical results from two experiments performed in triplicates are shown as the means \pm SEM. 
In the present study we decided to verify the assumption that dexamethasone might influence muscle cell differentiation and death in cultures of either rat L6 myoblasts or $\mathrm{C} 2 \mathrm{C} 12$ muscle cells and that these effects might be triggered or mediated by $\mathrm{H}_{2} \mathrm{O}_{2}$. Acute $24 \mathrm{~h}$ treatment of L6 muscle cells with Dex (1, 10, 100 nM) (Fig. 4) resulted in the similar picture of mitogenicity and anabolism as that found for $\mathrm{H}_{2} \mathrm{O}_{2}$ (Fig. 1). Chronic treatment of L6 myoblasts (10 days) or C2C12 satellite cells (5 days) with dexamethasone also caused protein synthesis to be affected similarly to that described for $\mathrm{H}_{2} \mathrm{O}_{2}$. At time-dependent increase of labelled leucine incorporation into the acid precipitable fraction of cellular proteins was observed for $2 \mathrm{nM}$ or $10 \mathrm{nM}$ of Dex for L6 myoblasts (Fig. 5) or C2C12 muscle cells (Fig. 6). The higher the dose the lower the protein synthesis. For $20 \mathrm{nM}$ (L6 cells) or $100 \mathrm{nM}$ (C2C12 cells) Dex the average values of protein synthesis did not considerably differ from the control. When $200 \mathrm{nM}$ (L6 cells) or $1000 \mathrm{nM}$ (C2C12 cells) of Dex was present in the medium, protein synthesis progressively diminished with an elapsed time, though no further

Figure 4. Mitogenic (filled bars) and anabolic (open bars) reactions of L6 muscle cells to Dex. The cells were incubated for $24 \mathrm{~h}$ with Dex $(1,10,100 \mathrm{nM})$. The typical results from three experiments are shown as the means \pm SEM of triplicate assays.

Figure 5. Timecourse of doseresponse curves illustrating the effect of chronic treatment (10 days) with Dex $(2,20,200 \mathrm{nM})$ on protein synthesis in cultures of L6 muscle cells. The typical results from two experiments performed in triplicate are shown as the means \pm SEM.

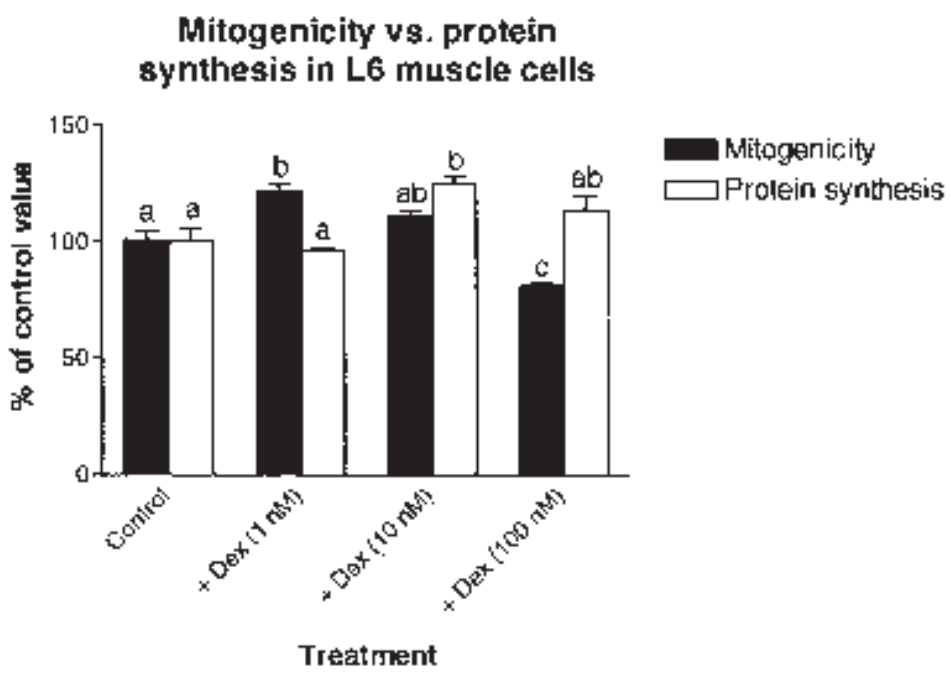

Protein synthesis in L6 muscle cells

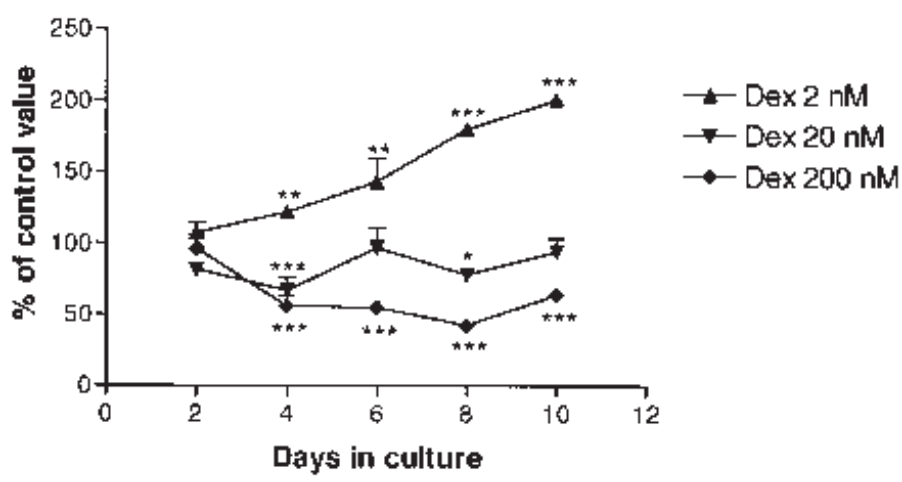


reduction was observed after the initial drop $(P<0.001)$. It turned out that the attenuated or inhibited synthesis of cellular proteins by $200 \mathrm{nM}$ or $1000 \mathrm{nM}$ Dex in differentiating L6 myoblasts or $\mathrm{C} 2 \mathrm{C} 12$ satellite cells, respectively, resulted from the impaired cell viability (Fig. 7; $P<0.001$ ). From day 4 up to day 10 , certain structural changes featured cell death (membrane blebbing, shrinkage and vacuolisation of the cytoplasm, peripheral chromatin condensation) were observed by the phase-contrast microscope after $200 \mathrm{nM}$ of Dex in L6 muscle cells in particular (Fig. 8). Only a few patches of dead L6 cells were found after $20 \mathrm{nM}$ of Dex at day 4, whereas extensive cell death was observed after $200 \mathrm{nM}$. In contrast to $\mathrm{H}_{2} \mathrm{O}_{2}$-induced cytotoxicity, after a 4-day treatment Dex (200 nM) did not induce oligonucleosomal fragmentation of DNA that could be detected in the wholecell lysates of L6 myoblasts (Fig. 9). Furthermore, the ultrastructural studies revealed apoptotic-like cell death with tags of

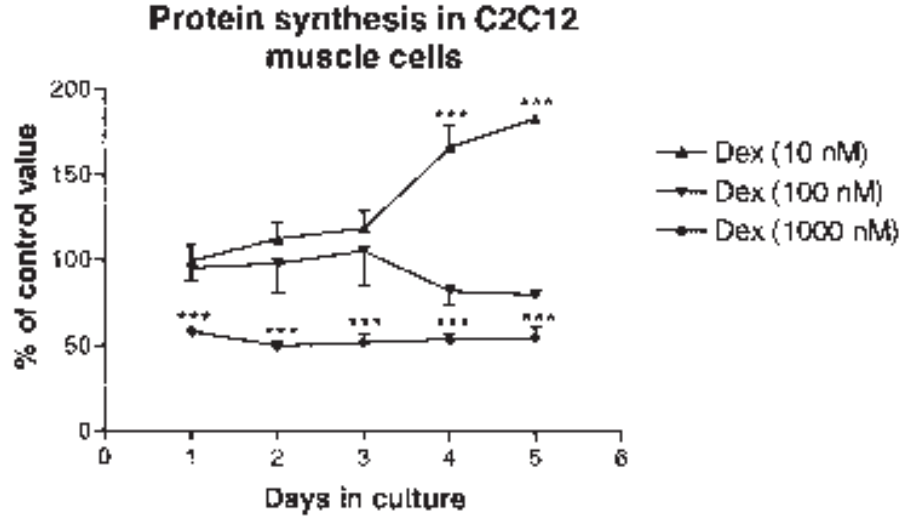

Figure 6. Timecourse of doseresponse curves representing the effect of chronic treatment (5 days) with Dex $(10,100,1000 \mathrm{nM})$ of $\mathrm{C} 2 \mathrm{C} 12$ satellite cells. The typical results from two experiments performed in triplicates are shown as the means \pm SEM.
Viability of L6
muscle cells

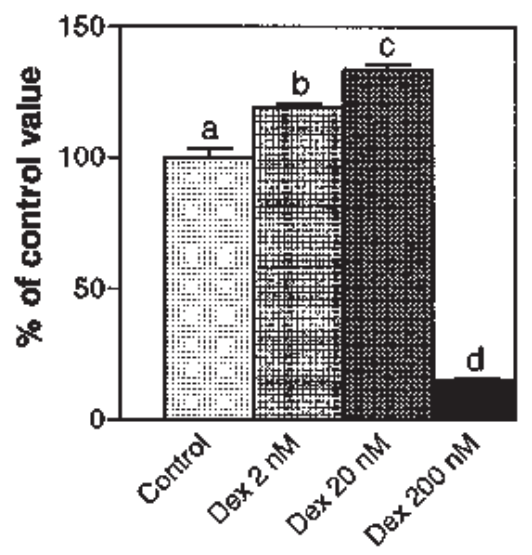

Treatment
Figure 7. Bar chart illustrating cell respiration (viability) measured by the conversion of soluble MTT into insoluble formazan at day 4 of chronic treatment of L6 muscle cells with Dex (2, 20, $200 \mathrm{nM})$. The typical results from three experiments performed in quadruplicates are shown as the means \pm SEM. 

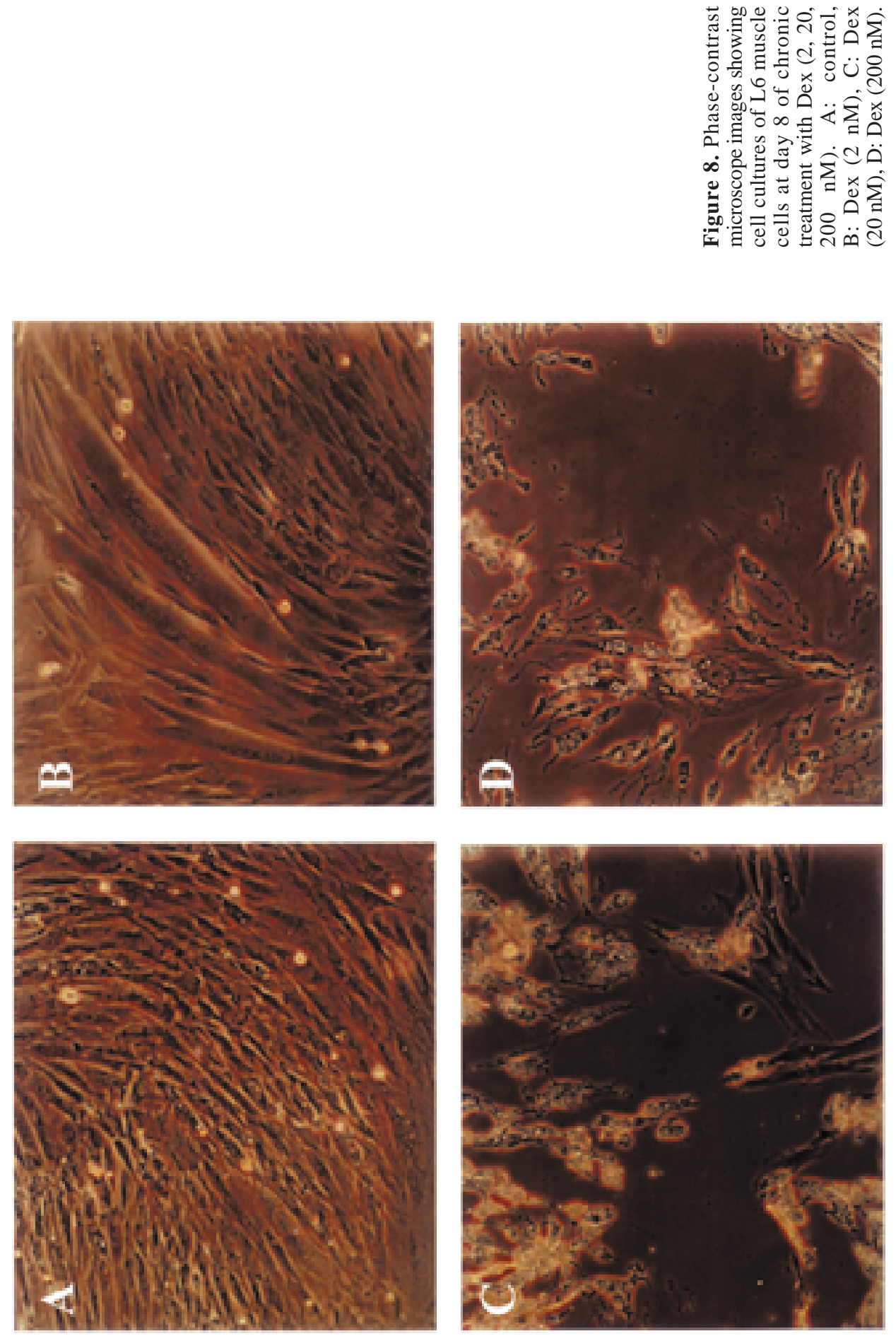


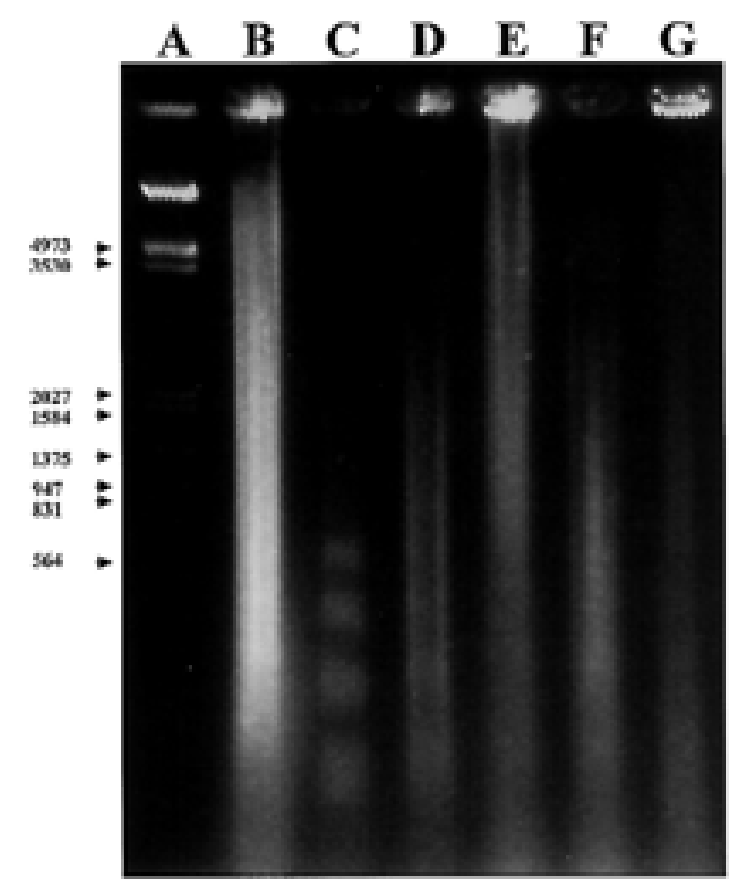

Figure 9. Agarose gel electrophoresis of DNA from whole-cell lysates obtained after 4 days of treatment with A: DNA molecular weight marker, B: control, C: UV-B $(24$ h), D: Dex $(200 \mathrm{nM}), \mathrm{E}:$ Dex $(200 \mathrm{nM})+$ Vit C $(1 \mathrm{mM}), \mathrm{F}:$ Dex $(200 \mathrm{nM})+\mathrm{NAC}$ $(1 \mathrm{mM}), \mathrm{G}:$ Dex $(200 \mathrm{nM})+\mathrm{CAT}$ $\left(1000 \mathrm{U} \cdot \mathrm{mL}^{-1}\right)$.

senescence caused by glucocorticoid excess such as an extensive vacuolisation, accumulation of inclusion-bodies and peripheral chromatin condensation (Fig. 10).

A one-day experiment on post-mitotic L6 myoblasts with increasing doses of Dex $(1,10,100 \mathrm{nM})$ brought a bar chart doseresponse picture of mitogenicity and anabolism that was strikingly consistent with the $\beta$-curve illustrating the concept of hormesis. At a low dose $(1 \mathrm{nM})$, mitogenicity was stimulated by Dex by $24 \%$, while at a higher dose $(100 \mathrm{nM})$ this index was reduced by $20 \%$. Protein synthesis was stimulated by $27 \%$ with $10 \mathrm{nM}$ Dex but by $15 \%$ with $100 \mathrm{nM}$ (Fig. 4).

Following the observations of the cell death promoting activity of Dex, we evaluated the influence of antioxidants on the synthesis of cellular proteins inhibited by the high doses of Dex (200 nM). We chose sodium ascorbate (ASC; 0.1 or $1 \mathrm{mM}$ ), $\mathrm{N}$-acetyl-L-cysteine (NAC; 0.1 or $1 \mathrm{mM}$ ) and typical catalase (CAT; 100 or $1000 \mathrm{U} \cdot \mathrm{mL}^{-1}$ ). Sodium ascorbate (sodium salt of vitamin C) abrogated Dex-dependent inhibition of protein synthesis significantly after $0.1 \mathrm{mM}$ and totally after $1 \mathrm{mM}$ (Fig. $11 ; P<0.001$ ). Similarly, the rate of protein synthesis reduced by Dex returned to control values or was stimulated on day 4, either with the highest dose of CAT $\left(1000 \mathrm{U} \cdot \mathrm{mL}^{-1}\right)$ or after NAC $(1 \mathrm{mM})$ (Fig. 11; $P<0.001)$. Lower doses of CAT $\left(100 \mathrm{U} \cdot \mathrm{mL}^{-1}\right)$ and NAC $(0.1 \mathrm{mM})$ were ineffective in protecting L6 muscle cells against the impaired synthesis of proteins induced by 200 nM Dex. The above-mentioned observations evaluated by morphological criteria were mirrored by the efficacy of ASC to rescue from Dex-mediated cell death (Figs. 11 and 12). These findings may indirectly corroborate the working hypothesis of the mediating role of $\mathrm{H}_{2} \mathrm{O}_{2}$ in the cytotoxic action of Dex excess. Moreover $\mathrm{H}_{2} \mathrm{O}_{2}$, Dex, Dex and antioxidants had a differential effect on the morphogenesis of the differentiating myoblasts; alterations 


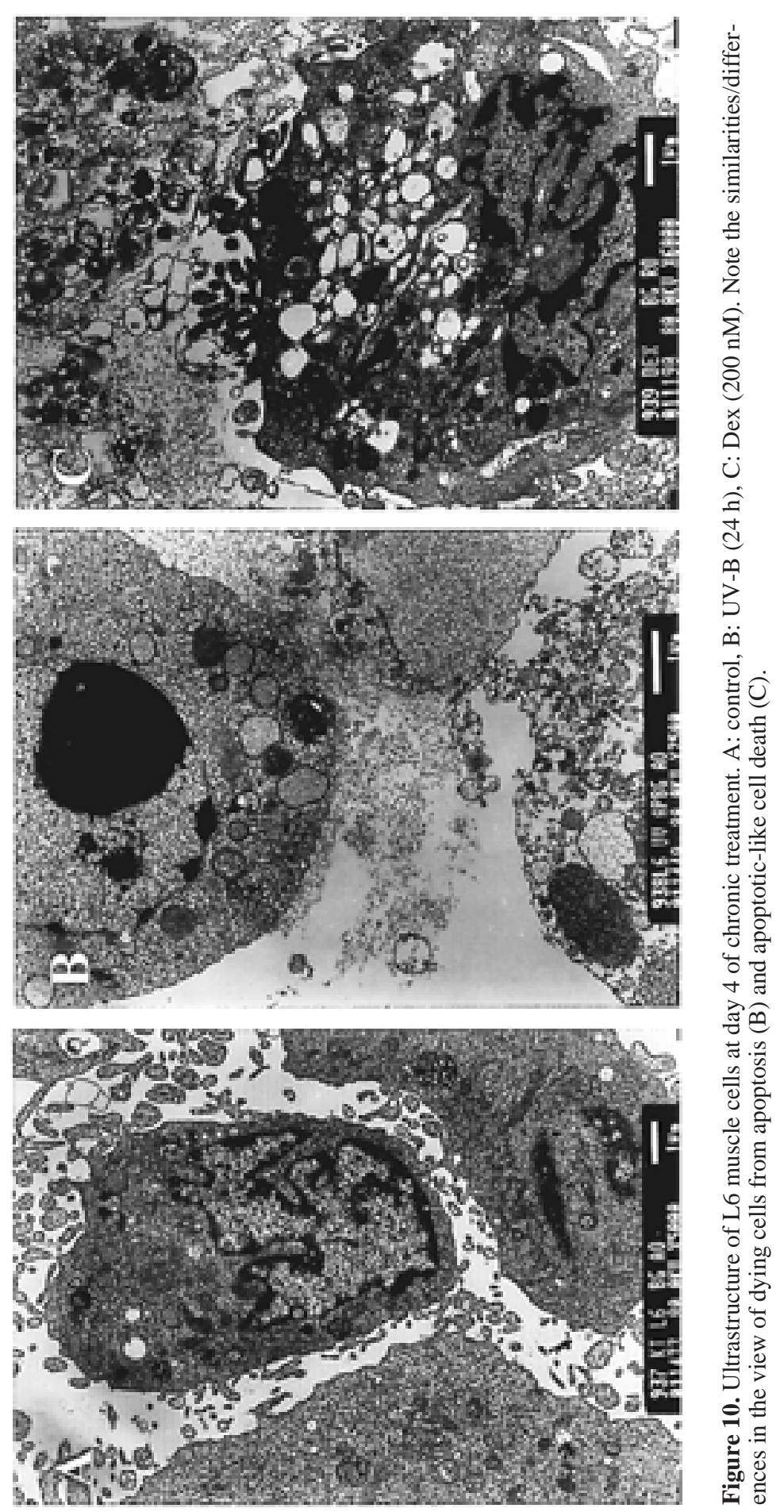




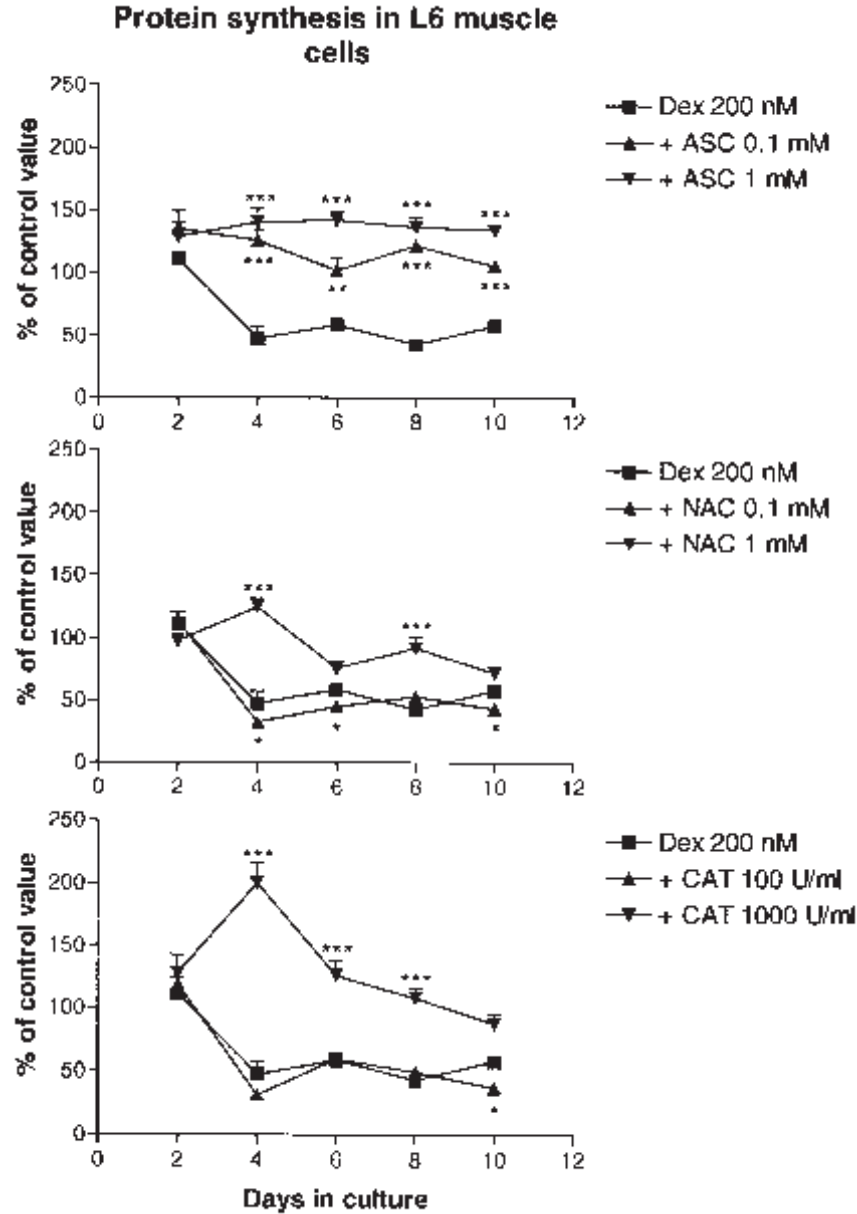

Figure 11. The effect of antioxidants on Dex-mediated inhibition of protein synthesis at day 4 of chronic treatment of L6 muscle cells. ASC: sodium ascorbate ( 0.1 , $1 \mathrm{mM}), \mathrm{NAC}$ : N-acetylL-cysteine $(0.1,1 \mathrm{mM})$ and CAT: catalase (100, $\left.1000 \mathrm{U} \cdot \mathrm{mL}^{-1}\right)$ were added with Dex (200 nM). The typical results from three experiments performed in triplicate are shown as the means \pm SEM in the view of cultured cells between the treatments could most likely result from the different amounts of $\mathrm{H}_{2} \mathrm{O}_{2}$ formed. Fusion of L6 muscle cells was accelerated by 2 days with $2 \mathrm{nM}$ Dex when confronted with the onset of fusion (day 10) observed in the control conditions (2\% HS/DMEM) (Fig. 8). Creatine kinase activity increased at day 8 instead of day 10 in L6 cell cultures treated with 2 nM Dex (data not shown). Similarly, when ASC (0.1 mM) was added with the highest Dex dose (200 nM), myogenesis was accelerated. Our results provide evidence that dexamethasone at low dose $(2 \mathrm{nM})$ markedly shortens the time gap to the onset of terminal differentiation of myoblasts.
Thus, the previously $[3,6]$ glucocorticoiddependent "boost" effect on muscle cell differentiation might evolve from higher abundance of $\operatorname{ROS}\left(\mathrm{H}_{2} \mathrm{O}_{2}\right)$. This suggestion is corroborated by the view that antioxidants, including specific $\mathrm{H}_{2} \mathrm{O}_{2}$ scavenger catalase, at higher doses abrogated the myogenic effect of Dex while at lower doses rescued the cells from Dex-induced cell death with concomitant stimulation of myogenesis.

As already mentioned, increasing the dose of Dex (2, 20, $200 \mathrm{nM})$ led to the progressive elimination of the cells with more than $85 \%$ of viable L6 cells being lost after the highest dose of Dex (Fig. 7; $P<0.001$ ) at day 4 . 
Figure 12. The effect of antioxidants on Dexmediated inhibition of viability at day 4 of chronic treatment with Dex (200 nM) of L6 muscle cells. Sodium ascorbate $(0.1$, $1 \mathrm{mM}$ ) was added with Dex $(200 \mathrm{nM})$. The typical results from three experiments performed in triplicate are shown as the means \pm SEM.
Viability of L6 muscle cells

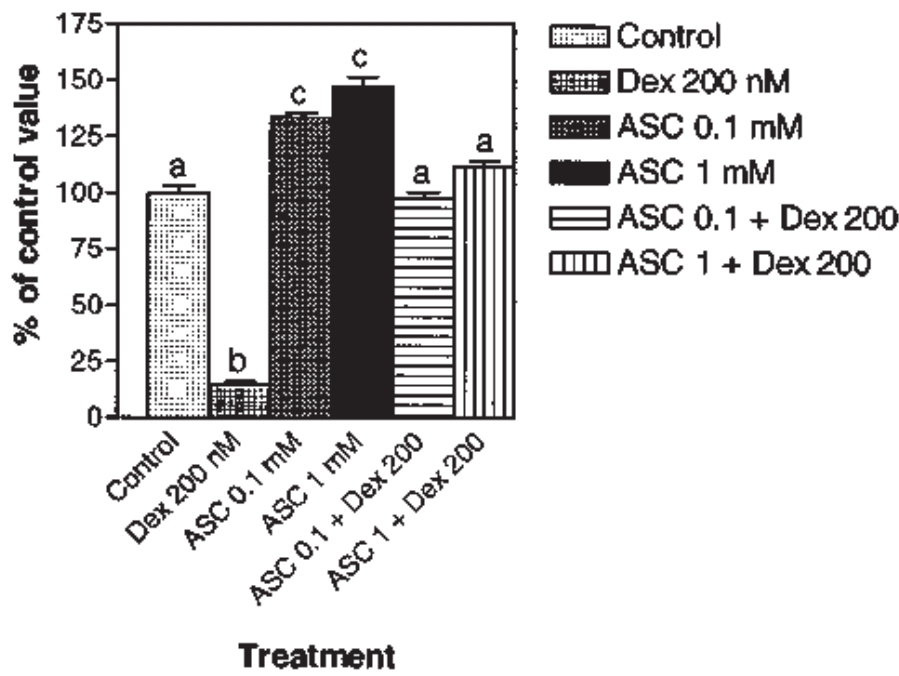

Sodium ascorbate - ASC (0.1 and $1 \mathrm{mM})$, or typical catalase - CAT $\left(1000 \mathrm{U} \cdot \mathrm{mL}^{-1}\right)$ or NAC ( $1 \mathrm{mM})$ each brought about a blockade of Dex-dependent L6 cell death with $100 \%$ efficacy (Figs. 11 and 12). In order to show the causal relationship between the glucocorticoids and $\mathrm{H}_{2} \mathrm{O}_{2}$ formation in muscle cells, we carried out the study directed on visualisation of $\mathrm{H}_{2} \mathrm{O}_{2}$ after Dex treatment by a specific marker (DCFH-DA). After a 3-day treatment with Dex and other experimental factors, the presence (or absence) of $\mathrm{H}_{2} \mathrm{O}_{2}$ was visualised by the reaction product dichlorofluorescein (DCF) in the fluorescent microscope while the differences were assessed with the use of automatic laser scanning cytometry and image analysis. A dose-dependent increase of $\mathrm{H}_{2} \mathrm{O}_{2}$ was observed after Dex treatment, while a marked reduction of $\mathrm{H}_{2} \mathrm{O}_{2}$ was found after ASC (1 mM) (Fig. 13).

\section{DISCUSSION}

The present study convincingly showed that changes in muscle cell development might be easily triggered by direct action of dexamethasone with a striking similarity to the action of $\mathrm{H}_{2} \mathrm{O}_{2} \cdot \mathrm{H}_{2} \mathrm{O}_{2}$ belongs to the cytotoxic molecules, which are potent stimulants of growth, differentiation, growth retardation, and cell death. In our studies it was shown that $\mathrm{H}_{2} \mathrm{O}_{2}$ did not stimulate mitogenicity, that is abrogated growth and induced apoptosis at higher concentrations. To a great extent, dexamethasone has growth modulation and necrobiotic effects which are similar to those of $\mathrm{H}_{2} \mathrm{O}_{2}$. When we added antioxidants, both $\mathrm{H}_{2} \mathrm{O}_{2}$ (data not shown) and Dex-induced apoptogenic effects were bypassed. We observed that CAT was equally effective with ASC and NAC in the protection against Dex-induced cell elimination. CAT is a potent and specific scavenger of $\mathrm{H}_{2} \mathrm{O}_{2}$ so we assume that $\mathrm{H}_{2} \mathrm{O}_{2}$ mediated this effect. Similar effects were observed by Tome et al. [44] when mouse thymoma cells were transfected with rat catalase. Moreover, in our experiment we measured the presence of $\mathrm{H}_{2} \mathrm{O}_{2}$ and observed a marked increase of $\mathrm{H}_{2} \mathrm{O}_{2}$ abundance in the cells treated with Dex. Thus, 

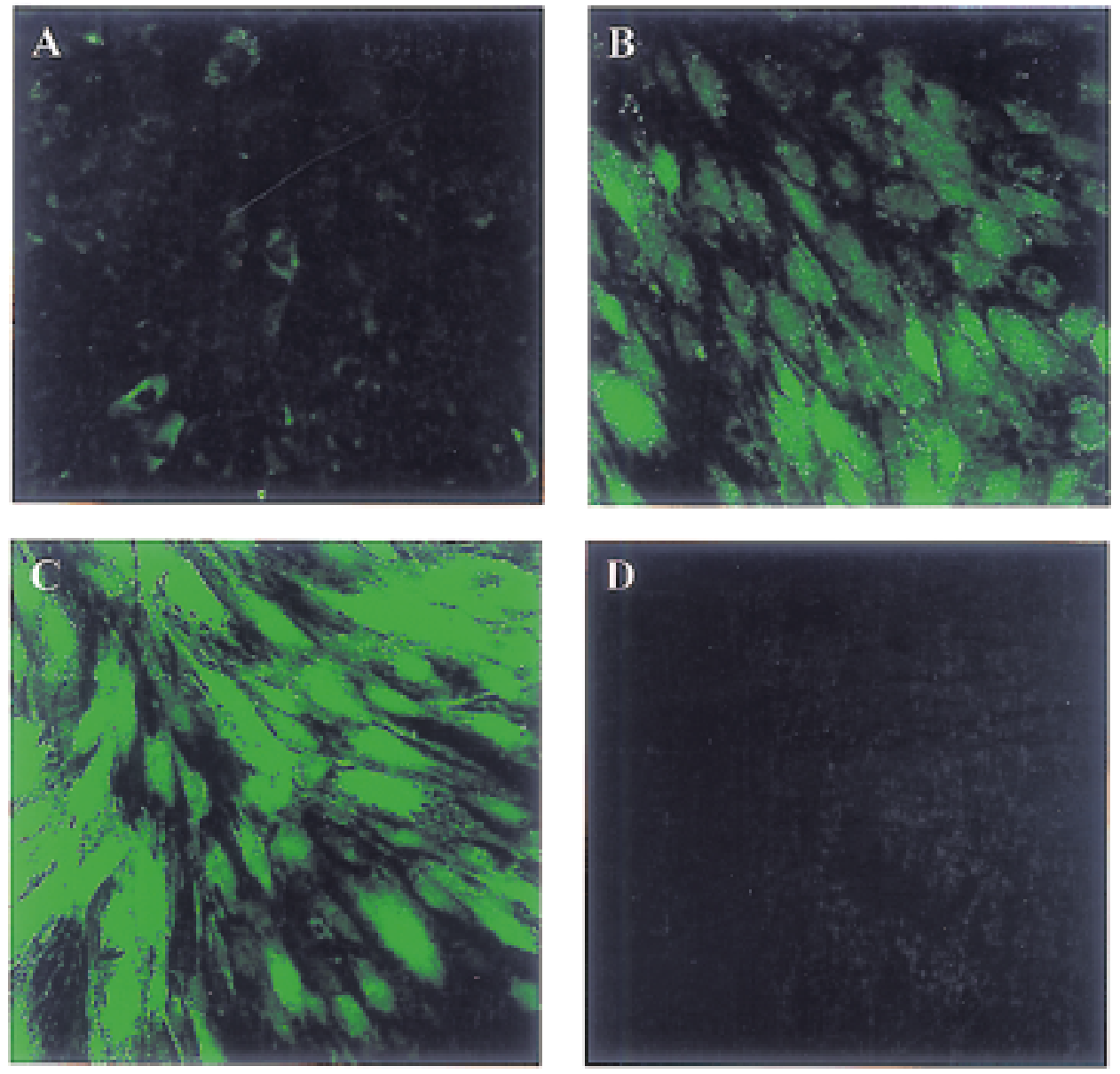

Figure 13. Images from the confocal microscope showing cell cultures of L6 muscle cells at day 3 of chronic treatment with A: control, B: $\mathrm{H}_{2} \mathrm{O}_{2}(100 \mu \mathrm{M})$; C: Dex $(200 \mathrm{nM})$, D: Dex $(200 \mathrm{nM})+$ Vit C (1 mM).

we conclude that $\mathrm{H}_{2} \mathrm{O}_{2}$ is a common signalling molecule that plays an important role in the regulation of the fate of mononuclear muscle cells. Recently, the concept of muscle cell activation by reactive oxygen species (ROS) was claimed by Anderson [2]. The author gave evidence that nitric oxide mediates satellite cell activation during muscle injury accompanied by $\mathrm{Ca}^{2+}$ influx. The proposed model assumes $\mathrm{NO}^{\circ}$ release, possibly via shear-induced rapid increase in NOS activity. Pharmacological inhibition of nitric oxide synthase (NOS) delays the hypertrophy of satellite cells. One should bear in mind, however, that nitric oxide at low concentrations (formed by constitutive forms of NOS) might act as a pseudo antioxidant (see the review [35]). Nitric oxide inhibits aconitase, ribonucleotidyl reductase, glutathione peroxidase, cytochrome $c$ oxidoreductase, NAD $(\mathrm{P}) \mathrm{H}$ oxidase, xanthine oxidase or caspases [20, $27,28,32]$. On the contrary shear stress which accompanies injured muscle also activates endothelial NAD(P)H oxidase with the superoxide anion radical being formed 
after dismutation to $\mathrm{H}_{2} \mathrm{O}_{2}$ which might easily diffuse and presumably activate/inactivate satellite cells [47]. Sundaresan et al. [42] the provided first evidence that the pathway by which ligand stimulation of ROS occurs in nonphagocytic cells involves the small GTP-binding proteins, Ras and Rac1. Formation of 3-phosphoinositides by PI-3K is crucial for binding through pleckstrinhomology domains of guanine nucleotide exchange factors (GEFs) specific for the Rho family of small GTPases, activates cdc42, Rac and Rho which then are able to interact with several downstream effectors including low output NAD $(\mathrm{P}) \mathrm{H}$ oxidase [36]. Expression of activated Ras or activated Rac1 isoforms resulted in increased generation of $\mathrm{O}_{2}{ }^{--}$, which is subsequently dismutated to $\mathrm{H}_{2} \mathrm{O}_{2}$ [21].

In muscle cells, we could not demonstrate a statistically significant increase of mitogenicity in response to $\mathrm{H}_{2} \mathrm{O}_{2}$ over a wide range of concentrations $(0.1-1000 \mu \mathrm{M})$. Nevertheless, our observations were in agreement with the data presented by Tournier et al. [45], who reported that the $\mathrm{H}_{2} \mathrm{O}_{2}$-induced stimulation of mitogen activated protein kinases - MAPK (extracellular signal regulated kinases - ERK1/2 and c-Jun activated N-terminal kinase - JNK) is accompanied by abrogated mitogenesis in non-stimulated or FGF-stimulated fibroblasts. It appears that the $\mathrm{H}_{2} \mathrm{O}_{2}$-induced mitogenicity is cell-type dependent or that cells generate $\mathrm{H}_{2} \mathrm{O}_{2}$ locally to evoke the necessary reactions with concomitant targeting on antioxidant enzymes. Superoxide dismutases, which eliminate $\mathrm{O}_{2}{ }^{\bullet-}$, subsequently generate $\mathrm{H}_{2} \mathrm{O}_{2}$. It should be emphasized, that in our study, mitogenicity was ameliorated by SOD-1, moreover, this enzyme affected protein synthesis, which mirrored the effect of $\mathrm{H}_{2} \mathrm{O}_{2}$. Not surprisingly, CAT, which scavenges $\mathrm{H}_{2} \mathrm{O}_{2}$, abrogated the mitogenic response rather than protein synthesis. The effect of both enzymes was neither synergistic nor additive but positive for both growth indices. Although it is not clear how adding large proteins such as CAT and
CuZnSOD to the culture media can block/activate events that are presumably occurring intracellularly, marked effects of these antioxidants are consistent with a role for oxidative stress in the mechanism of stimulation of growth, differentiation or cell death $[10,42]$.

Anabolic reactions elevated by $\mathrm{H}_{2} \mathrm{O}_{2}$ in muscle cells probably reflect the mechanism of antioxidant defenses triggered to synthesise rescue proteins. The issue of how and why antioxidant enzymes lead to similar effects remains ambiguous. Muscle cells synthesise proteins prior to division (proliferation) or when they are encouraged to differentiate. Since in this experiment $\mathrm{H}_{2} \mathrm{O}_{2}$ did not significantly stimulate mitogenesis we conclude that exaggerated synthesis of cellular proteins could result from the initiation of myogenesis and/or from the compensation of the losses of intracellular oxidised proteins that were efficiently degraded and eliminated by the proteolytic systems. Based on the assumption that muscle cell differentiation is dependent on prooxidantantioxidant homeostasis, we argue that mononuclear muscle cells are primed by $\mathrm{H}_{2} \mathrm{O}_{2}$ to synthesise antioxidant enzymes to the extent that prevents the initiation of myogenesis. Therefore, further studies directed to ascertain the effect of handicapped antioxidant defense systems on terminal differentiation (fusion) of myoblasts should be undertaken. Chronic treatment is needed to study myogenesis. To achieve at least in part this goal we conducted a 10-day experiment with increased doses of Dex. Apparently, in control conditions, L6 muscle cells started to form myotubes after 10 days of incubation (multinucleated postmitotic cells) but the process was significantly accelerated (8. day) after addition of Dex (2 $\mathrm{nM})$. Higher doses (20, $200 \mathrm{nM})$ eventually caused cell death before any symptoms of muscle cell fusion occurred (6th or 4th day of treatment, respectively). Nevertheless, some antioxidants could prevent cell elimination. ASC efficiently inhibited cytotoxicity of Dex, moreover $100 \mu \mathrm{M}$ of ASC 
unmasked glucocorticoid-dependent myogenesis. Our results provide evidence that at low concentrations, glucocorticoids are able to shorten the time gap to the onset of terminal differentiation (fusion).

Protein synthesis was stimulated by Dex but this effect was in adverse proportions to the dose such that the higher the dose, the lower the protein synthesis. Hence, Dex, at a low dose $(2 \mathrm{nM})$ was most efficient and by increasing cellular proteins in L6 muscle cells could be considered as a potent inducer of cell hypertrophy. Protein synthesis did not differ from the reference after $20 \mathrm{nM}$ of Dex. Dex, at high dose $(200 \mathrm{nM})$ inhibited protein synthesis in L6 cells but it turned out that this effect resulted from impaired cell viability rather than a retarded protein metabolism. The death-promoting effect of Dex was dose and time dependent. Extensive cell death occurred at day 4 after $200 \mathrm{nM}$ of Dex (Fig. 7). Since CAT (1000 U.mL ${ }^{-1}$ ), which is a specific scavenger of $\mathrm{H}_{2} \mathrm{O}_{2}$, abrogated the cell death promoting activity of Dex, we concluded that the cytotoxic effect of dexamethasone was mediated by $\mathrm{H}_{2} \mathrm{O}_{2}$. However, Dex-dependent necrobiology of mononuclear muscle cells differed from classical $\mathrm{H}_{2} \mathrm{O}_{2}$-induced cell death (Fig. 10). The appearance of muscle cell senescence was found instead of fragmented chromatin in the pictures obtained from the electron microscope after $200 \mathrm{nM}$ Dex treatment. This observation was in agreement with previous reports $[13,25]$ indicating that glucocorticoids might play a less clear physiological role in a progressive loss of muscle mass and developing mental dementia during ageing. The exact mechanism of glucocorticoid-induced cell death is unknown, although several reports indicate transcriptional glucocorticoid-mediated collapse of antioxidant systems with consequent ROS generation and an increase in calcium influx and structural deterioration of the cell $[5,8$, 9, 25, 26, 38]. Moreover, increased ROS activities and decreased activity of superoxide dismutases (SODs) and catalase as well as key enzymes of the glutathione
(GSH) redox cycle except glutathione S-transferase (GST) were observed in Dex treated lymphoblastic cell cultures and at the same time the process of programmed cell death (apoptosis) was accelerated [10]. Impaired viability, apoptosis or cell death induced by dexamethasone are mediated by the glucocorticoid hormone receptor (GHR) since GHR antagonists counteract the action of glucocorticoids [18, 23, 37, 43]. For lymphoblastic cells ( $\mathrm{T}$ cells) [48], thymocytes [15], dendritic cells [24], osteoblasts/osteocytes [46] and eosinophils [30], glucocorticoids are known to be apoptogenic and ROS mediate such forms of cell elimination [19]. Alternatively, the differences observed in our experiment between $\mathrm{H}_{2} \mathrm{O}_{2}$ and Dex action presumably resulted from higher $\mathrm{H}_{2} \mathrm{O}_{2}$ abundance and cell necrosis. As shown in an acute 24-h experiment in particular experimental conditions such as high concentrations of $\mathrm{H}_{2} \mathrm{O}_{2}$, this reactive oxygen species can also lead to oxidative events implicated in apoptosis and/or necrosis [14]

Thus, the same molecule might be an important module in the regulation of muscle differentiation but when its formation is excessive, or when the antioxidant defense is severely compromised due to biochemical demands or suppression by Dex, extensive generation of $\mathrm{H}_{2} \mathrm{O}_{2}$ may lead to various pathological conditions with consequent cell death by apoptosis and/or necrosis. Our studies indicate that the molarity factor is a principal determinant of whether $\mathrm{H}_{2} \mathrm{O}_{2}$ is detrimental to muscle function and development.

\section{ACKNOWLEDGEMENTS}

This study was supported by the State Committee for Scientific Research in Poland. The study was undertaken as a part of a project entitled "The regulation of growth, differentiation, ageing and death of myogenic cells" and summarises in part the results of experiments carried out during the years 1998-2000 of the Polonium Programme. 


\section{REFERENCES}

[1] Abu-Shakra S., Alhalabi M.S., Nachtmaan F.C., Schemidt R.A., Brusilow W.S.A., Anabolic steroids induce injury and apoptosis of differentiated skeletal muscle, J. Neurosci. Res. 47 (1997) 186-197.

[2] Anderson J.E., A role for nitric oxide in muscle repair: nitric oxide-mediated activation of muscle satellite cells, Mol. Biol. Cell 11 (2000) 1859-1874.

[3] Arnold T.E., Worrell R.A., Barth J.L., Morris J., Ivarie R., Dexamethasone-mediated induction of MMTV-myf-5 in DD3 myoblasts increases endogenous myogenin expression but does not transactivate $m y f-5$, Exp. Cell Res. 212 (1994) 321-328.

[4] Bae Y.S., Kang S.W., Seo M.S., Baines I.C., Tekle E., Chock P.B., Rhee S.G., Epidermal growth factor (EGF)-induced generation of hydrogen peroxide, J. Biol. Chem. 272 (1997) 217-221.

[5] Baker A.F., Briehl M.M., Dorr R., Powis P., Decreased antioxidant defence and increased oxidant stress during dexamethasone-induced apoptosis: bcl-2 prevents the loss of antioxidant enzyme activity, Cell Death and Diff. 3 (1996) 207-213.

[6] Ball E.H., Sanwall B.D., A synergistic effect of glucocorticoids and insulin on the differentiation of myoblasts, J. Cell. Physiol. 102 (1980) 27-36.

[7] Barja G., The flux of free radical attack through mitochondrial DNA is related to aging rate, Aging Clin. Exp. Res. 12 (2000) 342-355.

[8] Behl C., Effects of glucocorticoids on oxidative stress-induced hippocampal cell death: implications for the pathogenesis of Alzheimer's disease, Exp. Gerontol. 33 (1998) 689-696.

[9] Briehl M.M., Baker A.F., Modulation of the antioxidant defence as a factor in apoptosis, Cell Death Diff. 3 (1996) 63-70.

[10] Briehl M.M., Cotgrave I.A., Powis P., Downregulation of the antioxidant defence during glucocorticoid-mediated apoptosis, Cell Death Diff. 2 (1995) 41-46.

[11] Cai H., Harrison D.G., Endothelial dysfunction in cardiovascular diseases, The role of oxidant stress, Circ. Res. 87 (2000) 840-844.

[12] Calabrese E.J., Baldwin L.A., Hormesis as a biological hypothesis, Environ. Health Perspect. 106 (1998) 357-362.

[13] Dardevet D., Sornet C., Savary I., Debras E., Patureau Mirand P., Grizard J., Glucocorticoid effects on insulin- and IGF-I-regulated muscle protein metabolism during ageing, J. Endocrinol. 156 (1998) 83-89.
[14] Gardner A.M., Xu F.H., Fady C., Jacoby F.J., Duffey D.C., Tu Y., Lichtenstein A., Apoptotic vs. nonapoptotic cytotoxicity induced by hydrogen peroxide, Free Rad. Biol. Med. 22 (1997) 73-83.

[15] Gruber J., Sgonc R., Hu Y.H., Beug H., Eick G., Thymocyte apoptosis induced by elevated endogenous corticosterone levels, Eur. J. Immunol. 24 (1994) 1115-1121.

[16] Hansen L.L., Ikeda Y., Olsen G.S., Busch A.K., Mosthaf L., Insulin signalling is inhibited by micromolar concentrations of $\mathrm{H}_{2} \mathrm{O}_{2}$, J. Biol. Chem. 274 (1999) 25078-25084.

[17] Harman D., Aging: a theory based on free radical and radiation chemistry, J. Gerontol. 11 (1956) 298-300.

[18] Hechter O., Grossman A., Chatterton R.T. Jr. Relationship of dihydroepiandrosterone and cortisol in disease, Med. Hypoth. 49 (1997) 85-91.

[19] Hockenbery D.M., Oltvai Z.N., Yin X.M. Millman L.M., Korsmeyer S.J., Bcl-2 functions in an antioxidant pathway to prevent apoptosis, Cell 75 (1993) 241-251.

[20] Ichimori K., Fukahori M., Nakazawa H., Okamoto K., Nishino T., Inhibition of xanthine oxidase and xanthine dehydrogenase by nitric oxide, J. Biol. Chem. 274 (1999) 7763-7768.

[21] Irani K., Xia Y., Zweier J.L., Sollott S.J., Der C.J., Fearon E.R., Sundaresan M., Finkel T., Goldschmidt-Clermont P.J., Mitogenic signalling mediated by oxidants in Ras-transormed fibroblasts, Science 275 (1997) 1649-1652.

[22] Jacobson M.D., Burne J.F., Raff M.C., Programmed cell death and Bcl-2 protection in the absence of a nucleus, EMBO J. 13 (1994) 1899-1910.

[23] Kalimi M., Shafago Y., Loria R., Padgett D., Regelson W., Anti-glucocorticoid effects of dihydroepiandrosterone (DHEA), Mol. Cell. Biochem. 131 (1994) 99-104.

[24] Kim K.D., Choe Y.K., Choe I.S., Lim J.S., Inhibition of glucocorticoid-mediated, caspase-independent dendritic cell death by CD40 activation, J. Leukoc. Biol. 69 (2001) 426-434.

[25] Landfield P.W., Eldridge J.C., The glucocorticoid hypothesis of age-related hippocampal neurodegeneration: role of dysregulated intraneuronal calcium, Ann. N. Y. Acad. Sci. 746 (1994) 308-321.

[26] Landfield P.W., Eldridge J.C., Evolving aspects of the glucocorticoid hypothesis of brain aging: hormonal modulation of neuronal calcium homeostasis, Neurobiol. Aging. 15 (1994) 579-588.

[27] Leist M., Single B., Naumann H., Fava E., Simon B., Kuhnle S., Nicotera P., Nitric oxide inhibits execution of apoptosis at two distinct ATP-dependent steps upstream and downstream of mitochondrial cytochrome $\mathrm{c}$ release, Biochem. Biophys. Res. Commun. 258 (1999) 215-221. 
[28] Li Z.W., Chu W., Hu Y., Delhase M., Deerinck T., Ellisman M., Johnson R., Karin M., The IKK $\beta$ subunit of I $\mathrm{B}$ kinase (IKK) is essential for NF- $\mathrm{NB}$ activation and prevention of apoptosis, J. Exp. Med. 189 (1999) 1839-1845.

[29] Marshall C.J., Specificity of receptor tyrosine kinase signalling: transient versus sustained extracellular signal-regulated kinase activation, Cell 80 (1995) 179-185.

[30] Meagher L.C., Cousin J.M., Seckl J.R., Haslett C., Opposing effects of glucocorticoids on the rate of apoptosis in neutrophilic and eosinophilic granulocytes, J. Immunol. 156 (1996) 4422-4428.

[31] Miguel J., Economos A.C., Mitochondrial role in cell aging, Exp. Gerontol. 15 (1980) 575-591.

[32] Mohr S., Zech B., Lapetina E.G., Brune B., Inhibition of caspase- 3 by S-nitrosation and oxidation caused by nitric oxide, Biochem. Biophys Res. Commun. 238 (1997) 387-391.

[33] Morel Y., Barouki R., Repression of gene expression by oxidative stress, Biochem. J. 342 (1999) 481-496.

[34] Orzechowski A., Ostaszewski P., Brodnicka A., Wilczak J., Jank M., Balasilska B., Grzelkowska K., Ploszaj T., Olczak J., Mrówczylska A., Excess of glucocorticoids impairs whole body antioxidant status in young rats. Relation to the effect of dexamethasone in soleus muscle and spleen, Horm. Metab. Res. 32 (2000) 174-180

[35] Pfeiffer S., Mayer B., Hemmens B., Nitric oxide: chemical puzzles posed by a biological messenger, Angew. Chemistry Int. Ed. 38 (1999) 1714-1731.

[36] Roymans D., Slegers H., Phosphatidylinosito 3-kinases in tumor progression, Eur. J. Biochem. 268 (2001) 487-498.

[37] Sainz R.M., Mayo J.C., Reiter R.J., Antolin I., Esteban M.M., Rodriguez C., Melatonin regulates glucocorticoid receptor: an answer to its antiapoptotic action in thymus, FASEB J. 13 (1999) 1547-1556.

[38] Sanderson J., Marcantonio J.M., Duncan G., A human lens model of cortical cataract: $\mathrm{Ca}^{2+}$ induced protein loss, vimentin cleavage and opacification, Invest. Ophtalmol. Vis. Sci. 41 (2000) 2255-2261.
[39] Sarbassov D.D., Peterson C.A., Insulin receptor substrate-1 and phosphatidylinositol 3-kinase regulate extracellular signal-regulated kinasedependent and -independent signalling pathways during myogenic differentiation, Mol. Endocrinol. 12 (1998) 1870-1878.

[40] Sarbassov D.D., Jones L.G., Peterson C.A., Extracellular signal-regulated kinase-1 and -2 respond differently to mitogenic and differentiative signalling pathways in myoblasts, Mol. Endocrinol. 11 (1997) 2038-2047.

[41] Schlessinger J., Cell signalling by receptor tyrosine kinases, Cell 103 (2000) 211-225.

[42] Sundaresan M., Yu Z.X., Ferrans V.J., Sulciner D.J., Gutkind J.S., Irani K., GoldschmidtClermont P.J., Finkel T., Regulation of reactive-oxygen-species generation in fibroblasts by Rac1, Biochem. J. 318 (1996) 379-382.

[43] Thompson E.B., Apoptosis and steroid hormones, Mol. Endocrinol. 8 (1994) 665-673.

[44] Tome M.E., Baker A.F., Powis G., Payne C.M., Briehl M.M., Catalase-overexpressing thymocytes are resistant to glucocorticoid-induced apoptosis and exhibit increased net tumor growth, Cancer Res. 61 (2001) 2766-2773.

[45] Tournier C., Thomas G., Pierre J., Jacquemin C., Pierre M., Saunier B., Mediation by arachidonic acid metabolites of the $\mathrm{H}_{2} \mathrm{O}_{2}$-induced stimulation of mitogen-activated protein kinases (extracellular-signal-regulated kinase and c-Jun $\mathrm{NH}_{2}$-terminal kinase), Eur. J. Biochem. 244 (1997) 587-595.

[46] Weinstein R.S., Jilka R.L., Parfitt A.M., Manolagas S.C., Inhibition of osteoblastogenesis and promotion of apoptosis of osteoblasts and osteocytes by glucocorticoids. Potential mechanisms of their deleterious effects on bone, J. Clin. Invest. 102 (1998) 274-282.

[47] Yeh L.H., Park Y.J., Hansalia R.J., Ahmed I.S., Dehspande S.S., Goldsmidt-Clermont P.J., Irani K., Alevriadou B.R., Shear-induced tyrosine phosphorylation in endothelial cells requires Rac-1-dependent production of ROS, Am. J. Physiol. (Cell Physiol.) 276 (1998) C838-C847.

[48] Zacharchuk C.M., Mercep M., Chakraborti P.K., Simons S.S. Jr., Ashwell J.D., Programmed T lymphocyte death. Cell activation- and steroidinduced pathways are mutually antagonistic, J. Immunol. 145 (1990) 4037-4045. 